\title{
Some minerals and fatty acid compositions of five different wild edible mushrooms species collected in Tokat and Yozgat provinces in Turkey
}

${ }^{1,4}$ Bingöl University, Health Services Vocational School, Dept. of Medical Services and Techniques, Medical Laboratory Techniques Program, 12000, Bingöl, Turkey

${ }^{2}$ Tokat M. Emin Saraç Anatolian Religious High School, 60030, Tokat, Turkey

${ }^{3}$ Gaziosmanpaşa University, Science Faculty, Department of Biology, 60250, Tokat, Turkey

*abengu@bingol.edu.tr, ${ }^{2}$ hakanbiyoloji@gmail.com, ${ }^{3}$ ibrahim.turkekul@gop.edu.tr, ${ }^{4}$ h.platanus@gmail.com

Received : 04.03.2021

Accepted : 27.04.2021

Online : :01.05.2021

\section{Türkiye'de Tokat ve Yozgat illerinde toplanan beş farklı yenilebilir mantar türünün bazı mineralleri ve yağ asidi bileşimleri}

\begin{abstract}
The present study was made to determine the fatty acids composition and some minerals of five wild edible mushrooms species (Agaricus benesii (Pilát) Pilát, Amanita vaginata (Bull.) Lam., Leccinum aurantiacum (Bull.) Gray, Macrolepiota phaeodisca Bellù, Sarcodon imbricatus (L.) P. Karst.). Mushroom specimens, which were our research material, were collected from different localities in Tokat and Yozgat provinces. The minerals were examined in atomic absorption spectrophotometric (AAS) and fatty acids were detected by Gas chromatographic-mass spectrometry system (GC-MS) on dried mushrooms samples. In the result of analyses, six different minerals $(\mathrm{Cu}, \mathrm{Mn}, \mathrm{Zn}, \mathrm{Ni}, \mathrm{Fe}, \mathrm{Al})$ and six different fatty acids (pentadecanoic, palmitic, palmitoleic, stearic, oleic and linoleic acid) have been identified. The dominant fatty acid in basidiocarps of $A$. benesii and $M$. phaeodisca was linoleic acid (C18:2), and was determined as $62.58 \%$, 45.02\%, respectively. The dominant fatty acid in basidiocarps of A. vaginata, L. aurantiacum and S. imbricatus was oleic acid (C18:1), and was determined as $54.32 \%, 46.98 \%$ and $48.67 \%$, respectively. The most abundant mineral in basidiocarp of $S$. imbricatus was Zinc ( $\mathrm{Zn})$ with $112.29 \mathrm{mg} / \mathrm{kg}$. Also it was found that aluminium (Al) was the most abundant mineral in other ones with quantities ranging from $93.77-3349.02 \mathrm{mg} / \mathrm{kg}$.
\end{abstract}

Key words: AAS, GC-MS, nutrition, wild edible mushrooms, Turkey

Özet: $\mathrm{Bu}$ çalışma, beş yabani yenilebilir mantar türünün (Agaricus benesii (Pilát) Pilát, Amanita vaginata (Bull.) Lam., Leccinum aurantiacum (Bull.) Gray, Macrolepiota phaeodisca Bellù, Sarcodon imbricatus (L.) P. Karst.)'un yağ asitleri bileşimini ve bazı minerallerini belirlemek için yapılmış̧ır. Araştırma materyalimiz olan mantar örnekleri Tokat ve Yozgat illerinin farklı yörelerinden toplanmıştır. Kuru mantar örneklerinde mineraller atomik absorpsiyon spektrofotometrik (AAS) ve yağ asitleri Gaz kromatografik-kütle spektrometri sistemi (GC-MS) ile tespit edilmiştir. Analizler sonucunda altı farklı mineral $(\mathrm{Cu}, \mathrm{Mn}, \mathrm{Zn}, \mathrm{Ni}, \mathrm{Fe}, \mathrm{Al})$ ve altı farklı yağ asidi (pentadekanoik, palmitik, palmitoleik, stearik, oleik ve linoleik asit) tanımlanmıştır. Agaricus benesii ve M. phaeodisca'nın basidiokarplarında dominant yağ asidi linoleik asit (C18: 2) olup, sirasiyla \%62.58, \%45.02 olarak belirlenmistir. A. vaginata, L. aurantiacum ve S. imbricatus'un bazidiyokarplarında dominant yağ asidi oleik asit (C18: 1) olup, sırasıyla \%54.32, \%46.98 ve \%48.67 olarak belirlenmiştir. S. imbricatus'un basidiocarp'inda en bol bulunan mineral $112.29 \mathrm{mg} / \mathrm{kg}$ ile Çinko (Zn) idi. Ayrıca 93.77-3349.02 mg/kg arasında değișen miktarlarda alüminyumun (Al) diğerlerinde en bol bulunan mineral olduğu bulunmuştur.

Anahtar Kelimeler: AAS, GC-MS, beslenme, yabani yenilebilir mantar, Türkiye

Citation: Bengü AŞ, Işık H, Türkekul İ, Çınar Yılmaz H (2021). Some minerals and fatty acid compositions of five different wild edible mushrooms species collected in Tokat and Yozgat provinces in Turkey. Anatolian Journal of Botany 5(1): 58-64.

\section{Introduction}

Fungi are one of organisms having the most diverse in the world. Although it is estimated that there are 1.5 million fungi species in worldwide, 70 thousand of them are in the literature. About 10 thousand species of these recorded fungi are macrofungi including 5020 edible, 1250 inedible, 1010 poisonous, 1820 medicinal (Hawksworth, 1996, 2001; Pekşen, 2013).

Mushrooms are used in medicine as support for the treatment and prevention of many diseases, such as cardiovascular and inflammatory diseases. The nutrients used for these purposes are called nutraceutical. They have antioxidant, antitumor and antimicrobial properties. Mushrooms, one of these nutraceutical foods, attract attention with their low cholesterol, fat and carbohydrate content as well as basic nutritional elements. It has been recommended for people who diet with food having with high protein and low lipid content. Many studies have shown that mushrooms are excellent sources of essential unsaturated fatty acids. The unsaturated fatty acids are precursors for the synthesis of eicosanoids such as prostaglandins that are important for cardiovascular health. Oleic acid from the omega-9 family is a monounsaturated fatty acid, and is produced in our body. It is known as blood cholesterol lowering. Linoleic acid from the omega- 6 can not be synthesized by the human body. This fatty acid is very important for human health, especially to regulate blood lipid profiles. In addition, linoleic acid is used in the production of arachidonic acid, which is the polyunsaturated fatty acid from Omega-6 group, in our body (Barros, 2008; Riberio, 2009; Orsine, 2012; Ravikrishnan, 2015; Doğan, 2016).

The elements are inorganic substances that are not produced in the human body and must be taken from 
outside with liquid or solid foods. Minerals such as zinc, copper, iron and manganese are found in the human body in small amounts (approximately $0.02 \%$ of the total body weight or required in amounts $<100 \mathrm{mg} / \mathrm{day}$ ), and that's why they are called microelements (trace elements). These minerals must be taken from outside with nutrients even if their requirements are low. Zinc $(\mathrm{Zn})$ involved in the structure of some important metabolic enzymes such as polymerase, carbonic anhydrase, peptidase, alkaline phosphatase has important task in the metabolic functions of our body (wound healing, improved resistance against the infections, synthesis of nucleic acids and proteins etc.), and at protection of children against certain diseases. Copper $(\mathrm{Cu})$ is an important trace element involved in multiple enzyme systems such as ascorbic acid oxidase, cytochrome oxidase, monoamine oxidase, superoxide dismutase and lactase. It is also an essential element for the neurologic and hematologic systems. Manganese (Mn) takes part in the activation of enzymes such as superoxide dismutase, glycosyltransferase, pyruvate carboxylase. It is also involved in blood sugar regulation, fat and carbohydrate metabolism, normal brain and nerve functions, and calcium absorption. Iron ( $\mathrm{Fe}$ ) is used in metabolic processes such as DNA synthesis, electron and oxygen transport, production of hemoglobin and myoglobin, synthesis of connective tissue and some hormones. Nickel (Ni) is also accepted as ultra-trace nutrient. The functions of nickel in the human body have not been fully revealed. However, it is thought that it is a cofactor of some enzymes involved in the metabolism of glucose. Also it is a toxic mineral for many systems in human body. Contact with nickel can cause the allergic reactions on skin such as contact dermatitis. Some studies have shown that it causes respiratory cancers (Wada, 2004; Duda-Chodak, 2008; Al-Fartusie, 2017). Aluminum (Al) is the toxic microelement for human body, in spite of the fact that it is the most abundant metal in the earth's crust. It has an inhibitory effect for many biological functions (Kawahara, 2007).

The aim of this study was to examine the composition of some mineral and fatty acids of five edible mushroom species, namely Agaricus benesii, Amanita vaginata, Leccinum aurantiacum, Macrolepiota phaeodisca, and Sarcodon imbricatus.

\section{Materials and Method}

\subsection{Collection and Identification of Mushroom Samples}

During regular field trips, mushroom samples were collected from different regions in Tokat and Yozgat provinces and fatty acid and mineral analysis were made. The habitats, localities and families of the samples are given in Table 1.

The fresh specimens were photographed in the field, and their macroscopic and ecological features were noted. They were brought to the laboratory and the collection numbers were given to each. Afterly the specimens were dried and put into polyethylene bags for later studies. Characteristics of microscopical structures were investigated under a light microscope by mounting them in some reagents (lactofenol stain, Melzer's reagent, congo red, $\mathrm{KOH} 5 \%$, distilled water etc). The specimens were identified based on their ecological, macroscopic and microscopic features with the literature such as Philips (1981), Moser (1983), Bon (1987), Jordan (1995) and Breitenbach and Kränzlin (1995). The examined specimens were deposited in the Fungarium of Biology Department, Gaziosmanpaşa University, Tokat, Turkey.

\subsection{Fatty acid analysis}

The fatty acids were detected by gas chromatographicmass spectrometry instrument (GC-MS, Agilent 7890 GC/5970 MS Series-Santa Clara, CA, USA) using the conditions in Table 2 , and a high polarity capillary column (HP-88, $100 \mathrm{~m} \times 0.25 \mathrm{~mm}, 0.20$ um film (Part no: 112 88A7, Agilent, Santa Clara, CA, USA). Dried and ground mushroom samples were used in chemical analyzes. The method of Hara and Radin (1978), for lipid extraction and Christie (1990), Christie (1998) and Wretensjö (1990), process to obtain methyl esters was revised and used. For this purpose, $5 \mathrm{~g}$ of dried mushroom samples were taken and broken in $10 \mathrm{~mL}$ of hexane/isopropanol (3:2) in homogenizer at $10.000 \mathrm{rpm}$ for 30 seconds. After then, the mixture was centrifuged at $5000 \mathrm{rpm}$ for 10 minutes, the upper part was taken, and filtered and then it was put into test tubes. The lipid extract was transferred to cap tubes $(30 \mathrm{~mL})$ to prepare the methyl ester. $5 \mathrm{~mL}$ of $2 \%$ methanolic sulfuric acid was added into the extract and it was vortexed. This mixture was held for methylation in the incubator at $50^{\circ} \mathrm{C}$ for 15 hours. After then, the tubes were removed from the incubator and cooled to room temperature and vortexed with the addition of $5 \mathrm{~mL}$ of $5 \%$ $\mathrm{NaCl}$. The methyl esters of the fatty acids formed in the tubes were extracted with $5 \mathrm{~mL}$ of hexane. The hexane phase was taken from the top with a Pasteur pipette and treated with $5 \mathrm{~mL}$ of $2 \% \mathrm{KHCO}_{3}$ and kept for 1-2 hours to separate the phases. The solvent of the mixture containing the methyl esters was evaporated under nitrogen at $45^{\circ} \mathrm{C}$. Fatty acids at the under of the test tubes were dissolved with $1 \mathrm{~mL}$ of hexane and analyzed with GC-MS by transferring to dark GC vials. SGE Analytical (BP×90 100 $\mathrm{m} \times 0.25 \mathrm{~mm} \times 0.25 \mathrm{um}$ ) column (Australia) and Agilent brand GC-MS instrument were used in our study. The temperature was gradually increased from $120^{\circ} \mathrm{C}$ to $250^{\circ} \mathrm{C}$ within 45 minutes and kept at this temperature during the analysis. In the analysis of the samples, Helium (He) was selected as the carrier gas. The system was calibrated with the standard fatty acid samples and natural fatty acids in the samples were determined. All analyzes were carried out in triplicate and average of the results were taken. The results of fatty acids methyl ester were reported as percentage (Bengü, 2019).

\subsection{Mineral analysis}

The minerals were examined in atomic absorption spectrophotometric instrument (AAS, Perkin Elmer brand AAS 800 Model, USA). In the preparation of the samples, approximately $0.5 \mathrm{~g}$ of the dried mushroom samples were weighed and transferred to the microwave oven teflon containers, and $10 \mathrm{~mL}$ nitric acid was added to each sample and burned in the microwave. The samples were read with each element wavelength, specific lamp, and standard graphics in AAS studies. The studies had been made in the form of three repetitions and were averaged. The data of mineral analysis were reported as $\mathrm{mg} / \mathrm{kg}$. 


\section{Results}

The results of fatty acid analysis of the five wild edible macrofungi species and the amounts of total saturated

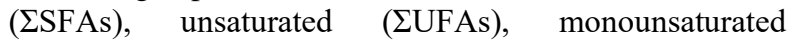

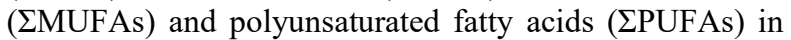
the analyzed samples were given in Table 3.

According to the results, six different saturated (pentadecanoic, palmitic and stearic acid) and unsaturated fatty acids (palmitoleic, oleic and linoleic acid), which carbon chain lengths ranging from 14-24, have been detected in quantities ranging from $1.61 \%$ to $62.58 \%$ from five wild edible mushrooms (A. benesii, A. vaginata, $L$. aurantiacum, M. phaeodisca, S. imbricatus) collected from different localities in Tokat and Yozgat provinces in Turkey. As a result of the analysis of the samples, short chain fatty acids could not be detected due to the destruction and loss of fatty acids as a result of the temperature applied during the preparation and methylation of the extraction. It has been reported that short-chain fatty acids, which are liquid at room temperature, evaporate easily at high temperatures (Woldegiorgis, 2015). The highest rate of total saturated fatty acid was found in $M$. phaeodisca with $43.11 \%$ due to the high levels of palmitic acid $(30.70 \%)$, while the lowest of total saturated fatty acid was found in L. aurantiacum with $21.65 \%$. The highest rate of total unsaturated fatty acid was determined in L. aurantiacum with $78.35 \%$ due to the high levels of oleic acid (46.98\%) and linoleic acid (31.37\%), while the lowest of total unsaturated fatty acid was determined in $M$. phaeodisca with $56.89 \%$. Also it was determined that the unsaturated fatty acid levels

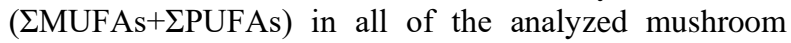
species samples was higher than the saturated fatty acid levels (Table 3). This result is consistent with previous studies such as Ribeiro et al. (2009), Ravikrishnan et al. (2015), Yılmaz et al. (2006), Ergönül et al. (2012), Doğan and Akbaş (2013), Goyal et al. (2015), Pietrzak-Fiećko et al. (2016), Türkekul et al. (2017), Bengü (2019) and Bengü et al. (2019). $\Sigma$ PUFAs amount was higher in $A$. benesii and $M$. phaeodisca samples, and $\Sigma$ MUFAs was higher in A. vaginata and $S$. imbricatus. Because of the major fatty acid was linoleic acid, which is the precursor of mushroom alcohol (1-octen-3-ol), was found in the samples of $A$. benesii and $M$. phaeodisca with $62.58 \% \neg 45.02 \%$, respectively. The major fatty acid was oleic acid in the samples of A. vaginata, L. aurantiacum and $S$. imbricatus with $54.32 \%, 46.98 \%$ and $48.67 \%$, respectively. While pentadecanoic acid with $1.83 \%$ was observed only in L. aurantiacum species, palmitoleic acid was observed only in $M$. phaeodisca species. Palmitic, stearic, oleic and linoleic acid were determined in different amounts in all mushroom samples (Table 3). The main fatty acid in mushrooms was found to be linoleic acid, followed by oleic acid and palmitic acid as were in many studies, such as Akyüz (2011) Goyal (2015), Pietrzak (2016) and Bengü et al. (2019). Our results are consistent with the results of these studies.

In literature review, any work on the fatty acid profiles of A. benesii could not detected. In our studies made on this mushroom; palmitic, stearic, oleic and linoleic acids were detected with proportions of $19.95 \%, 12.59 \%, 4.88 \%$ and $62.58 \%$, respectively (Table 3 ). In a similar study made with Agaricus bisporus and Pleurotus sajor caju by Goyal et al. (2015), seven different fatty acids have been identified including palmitic, stearic, oleic and linoleic acid. Arachidic acid, which we could not detect in our study, was found in studies made with Agaricus bisporus and A. campestris by Yilmaz et al. (2006). In a study made on natural specimens of $A$. bisporus by Bengü et al. (2019), nine different fatty acids (myristic, penthadecanoic, palmitic, heptadecanoic, stearic, oleic, linoleic, eicosenoic, behenic acid) have been identified. Unlike this result, myristic, penthadecanoic, heptadecanoic, eicosenoic, behenic acid could not be detected in $A$. benesii samples which we used in our studies.

In our studies made with Amanita vaginata, four different fatty acids (palmitic, stearic, oleic and linoleic acid) were found with proportions of $20.68 \%, 4.81 \%, 54.32 \%$ and $20.19 \%$, respectively (Table 3 ). The fatty acids of $A$. rubescens has been analyzed in a similar study made by Ribeiro et al. (2009). Twenty one different fatty acids have been detected in the result of this study. The rates of palmitic, stearic, oleic and linoleic acid which we were identified in our work were higher than the others. In a study made by Karliński et al. (2007), A. muscaria and A. rubescens were analyzed for the determination of fatty acids content. The dominant fatty acid in basidiocarps of A. muscaria was linoleic acid. In addition tridesilic acid (C13:0) was found to be the dominant fatty acid in $A$. rubescens.

In the chemical analysis of L. aurantiacum, five different fatty acids (pentadecanoic, palmitic, stearic, oleic and linoleic acid) were found with proportions of $1.83 \%$, $14.93 \%, 4.89 \%, 46.98 \%$ and $31.37 \%$, respectively (Table $3)$. Pentadecanoic acid could only be detected in this mushroom among the fungi which we analyzed. In this study made to determine fatty acid composition of $L$. aurantiacum species by Pedneault et al. (2006), the major fatty acid was linoleic acid. In our studies, we found that the highest amount of fatty acid is oleic acid. In the study made with $L$. scabrum by Karliński et al. (2007), linoleic acid was identified to be the most abundant fatty acid with proportions of $72.6 \%$. In addition, in this study made on $L$. scabrum by Dembitsky et al. (2010), oleic acid and linoleic acid was found to be the most abundant fatty acids with proportions of $31.7 \%$ and $45.8 \%$, respectively.

In literature searches, any work made on the fatty acid profiles of $M$. phaeodisca could not detected. However, there are studies made with similar species such as Macrolepiota procera, M. mastoidea. Palmitic, palmitoleic, stearic, oleic and linoleic acid were found with proportions of $30.70 \%, 2.01 \%, 12.41 \%, 9.86 \%$ and $45.02 \%$, respectively in analysis that we made with the test samples of $M$. phaeodisca (Table 3). In the result of study made by Barros et al. (2008), it was detected that the proportion of palmitic, oleic and linoleic acid was higher than others in the dry samples of Macrolepiota procera and Macrolepiota mastoidea. In this study made on Macrolepiota procera by Fernandesa et al. (2013), linoleic acid was detected as the major fatty acid compared to other fatty acids.

In the chemical analysis of $S$. imbricatus, four different fatty acids (palmitic, stearic, oleic and linoleic acid) were found with proportions of $15.95 \%, 8.93 \%, 48.67 \%$ and $26.45 \%$, respectively (Table 3 ). Pentadecanoic and palmitoleic acid were not found in our samples. Oleic and 
linoleic acid were detected in our study as the major fatty acids. The studies made on dry samples of $S$. imbricatus by Barros et al. (2007) were showed that the major fatty acids were palmitic, stearic, oleic and linoleic acids as in our results.

According to the results of mineral analysis, six different minerals $(\mathrm{Cu}, \mathrm{Mn}, \mathrm{Zn}, \mathrm{Ni}, \mathrm{Fe}, \mathrm{Al})$ have been detected in quantities ranging from $4.81 \mathrm{mg} / \mathrm{kg}$ to $3349.02 \mathrm{mg} / \mathrm{kg}$ from five wild edible mushrooms (A. benesii, A. vaginata, L. aurantiacum, $M$. phaeodisca, $S$. imbricatus) collected from different localities in Tokat and Yozgat provinces in Turkey (Table 4, Figure 1).

While copper $(\mathrm{Cu})$ was found at the highest level in $S$. imbricatus with $66.16 \mathrm{mg} / \mathrm{kg}$, it was found at the lowest level in L. aurantiacum with $41.11 \mathrm{mg} / \mathrm{kg}$. Manganese (Mn) was found at most in A. vaginata with $69.90 \mathrm{mg} / \mathrm{kg}$, it was found at lowest in $S$. imbricatus with $7.18 \mathrm{mg} / \mathrm{kg}$. The lowest and highest levels of Zinc ( $\mathrm{Zn}$ ) were found in M. phaeodisca (with $53.68 \mathrm{mg} / \mathrm{kg}$ ) and S. imbricatus (with $112.29 \mathrm{mg} / \mathrm{kg}$ ), respectively. In our research, the amount of nickel (Ni) was found to be higher in A. vaginata with $15.29 \mathrm{mg} / \mathrm{kg}$ than the others, and the lowest value of this mineral was measured in M. phaeodisca with $4.81 \mathrm{mg} / \mathrm{kg}$. Iron $(\mathrm{Fe})$ mineral was measured at the most level in $A$. vaginata with $1631.86 \mathrm{mg} / \mathrm{kg}$, and the least level of it was observed in S. imbricatus with $35.45 \mathrm{mg} / \mathrm{kg}$ was observed at the least amount in this mushroom. In addition, the analysis showed that aluminum $(\mathrm{Al})$ was at the highest level in A. vaginata with $3349.02 \mathrm{mg} / \mathrm{kg}$ and was at the lowest level in M. phaeodisca with $93.77 \mathrm{mg} / \mathrm{kg}$. In result the highest concentration of $\mathrm{Mn}, \mathrm{Ni}, \mathrm{Fe}$ and $\mathrm{Al}$ was observed in A. vaginata with $69.90,15.29,1631.86$, $3349.02 \mathrm{mg} / \mathrm{kg}$, respectively, and the the highest concentration of $\mathrm{Cu}$ and $\mathrm{Zn}$ was observed in S. imbricatus with $66.16-112.29 \mathrm{mg} / \mathrm{kg}$, respectively.

In the present study, $\mathrm{Cu}, \mathrm{Mn}, \mathrm{Zn}, \mathrm{Ni}, \mathrm{Fe}, \mathrm{Al}$ contents were $58.96,15.74,97.43,9.62,85.95$ and $309.10 \mathrm{mg} / \mathrm{kg}$ in Agaricus benesii and 60.25, 69.90, 104.61, 15.29, 1631.86 and $3349.02 \mathrm{mg} / \mathrm{kg}$ in Amanita vaginata, respectively (Table 4). In study made for Agaricus xanthodermus by Jonnalagadda et al. (2006), Fe and Mn have been detected to be $306 \mathrm{mg} / \mathrm{kg}$ and $30 \mathrm{mg} / \mathrm{kg}$, respectively. Agaricus bisporus from Agaricus genus is one of the most studied fungi in the world. In study made on A. bisporus by Işıldak et al. (2004), they found that $\mathrm{Fe}$ was the dominant element followed by $\mathrm{Cu}$ and $\mathrm{Zn}$. Amanita vaginata is an edible macrofungi that naturally collected and consumed in many regions in Turkey. $\mathrm{Cu}, \mathrm{Mn}, \mathrm{Zn}, \mathrm{Ni}, \mathrm{Fe}, \mathrm{Al}$ were determined in quantities ranging from $15.29 \mathrm{mg} / \mathrm{kg}$ to $3349.02 \mathrm{mg} / \mathrm{kg}$ in our A. vaginata samples collected from different area of Tokat province. The study made on $A$. vaginata by Radulescu et al. (2010). $\mathrm{Cu}, \mathrm{Mn}, \mathrm{Zn}, \mathrm{Ni}, \mathrm{Fe}$ were determined in quantities ranging from $0.7 \mathrm{mg} / \mathrm{kg}$ to $112.10 \mathrm{mg} / \mathrm{kg}$. Zn content was higher in this study than our results. But $\mathrm{Cu}, \mathrm{Mn}, \mathrm{Ni}, \mathrm{Fe}$ amounts in our study were higher than the results of the study made by Radulescu et al. (2010).

In addition $\mathrm{Cu}, \mathrm{Mn}, \mathrm{Zn}, \mathrm{Ni}, \mathrm{Fe}, \mathrm{Al}$ contents were 41.11, $19.30,77.33,9.10,227.38$ and $480.28 \mathrm{mg} / \mathrm{kg}$ in $L$. aurantiacum and $61.18,10.33,53.68,4.81,53.92$ and $93.77 \mathrm{mg} / \mathrm{kg}$ in $M$. phaeodisca, respectively (Table 4). Trace minerals $(\mathrm{Cu}, \mathrm{Mn}, \mathrm{Zn}, \mathrm{Fe})$ that we found in the studies were detected by Brzezicha-Cirocka et al. (2016) from $L$. aurantiacum samples with 37, 17, 100 and 150 $\mathrm{mg} / \mathrm{kg}$, respectively. According to this, our results are higher in terms of these minerals than the results of Brzezicha-Cirocka et al. (2016). In literature searches, any work made on the mineral content of Macrolepiota phaeodisca could not detect. But in a study made on a close species (M. procera) by Keleş et al. (2017), Cu, Mn, $\mathrm{Zn}, \mathrm{Fe}$ and $\mathrm{Ni}$ were determined in quantities ranging from 6.98 to $151.5 \mathrm{mg} / \mathrm{kg}$. In our studies copper content was found to be higher according to other study, and iron content was higher at the study made by Keleş et al. (2017).

In analysis of $S$. imbricatus samples; the amounts of $\mathrm{Cu}$, $\mathrm{Mn}, \mathrm{Zn}, \mathrm{Ni}, \mathrm{Fe}$ and $\mathrm{Al}$ were found as 66.16, 7.18, 112.29, $5.38,35.45,94.49 \mathrm{mg} / \mathrm{kg}$, respectively. Among mushroom species analyzed, the greatest concentrations of $\mathrm{Cu}$ an $\mathrm{Zn}$ were obtained in $S$. imbricatus with $66.16 \mathrm{mg} / \mathrm{kg}$ and $112.29 \mathrm{mg} / \mathrm{kg}$, respectively. In a study made to determine the amount of $\mathrm{Zn}, \mathrm{Mn}, \mathrm{Fe}$ and $\mathrm{Cu}$ on dry samples of the same macrofungi by Çolak et al. (2009), it was determined that $\mathrm{Zn}$ was the highest amount mineral compared to other minerals like our study. Although the amount of copper at our studies is higher compared to the study made by Çolak et al. (2009). The amont of Mn detected by Çolak et al. (2009) is higher than our study.

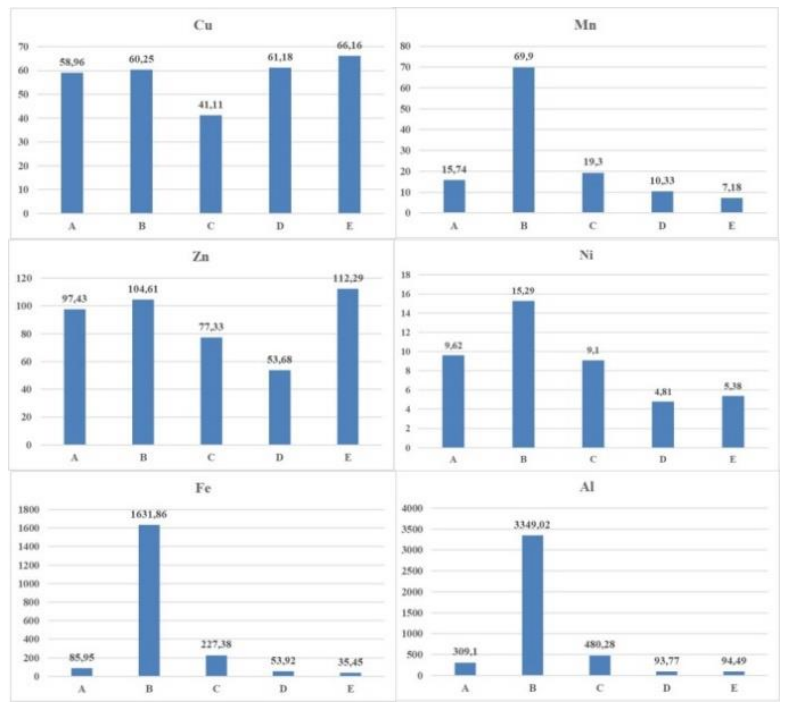

Figure 1. Microminerals levels of mushroom samples (mg/kg)

Table 1. Some features of the mushroom species

\begin{tabular}{llll}
\hline Species & Family & Localities & Habitat \\
\hline Agaricus benesii & Agaricaceae & Yozgat-Akdağmadeni & Under deciduous trees \\
Amanita vaginata & Amanitaceae & Tokat center & In broad-leaf woods \\
Leccinum aurantiacum & Boletaceae & Tokat center & On soil under poplar \\
Macrolepiota phaeodisca & Agaricaceae & Yozgat-Kadışehri & On soil under oak \\
Sarcodon imbricatus & Bankeraceae & Yozgat-Akdağmadeni & In coniferous woods \\
\hline
\end{tabular}


Table 2. GC-MS analytical conditions for fatty acid analysis

\begin{tabular}{ll}
\hline Parameter/Component & Description / Value \\
\hline GC-MS instruments & Agilent- Santa Clara, CA, USA \\
Series & $7890 \mathrm{GC} / 5970 \mathrm{MS}$ \\
Column & SGE Analytical BP×90 100m $\times$ \\
& $0.25 \mathrm{~mm} \times 0.25 \mathrm{um}$ (Australia) \\
Detector & FID for GC, Triple-axis for MS \\
Auto sampler & $\mathrm{CTC}-\mathrm{PAL}$ \\
Temperature program & $120^{\circ} \mathrm{C}$ to $250^{\circ} \mathrm{C}, 5^{\circ} \mathrm{C} / \mathrm{min}$. with \\
& temperature rise rate \\
Total time & $45 \mathrm{~min}$. \\
Split ratio & $10: 1$ \\
Injection volume & $1 \mu \mathrm{L}$ \\
Solvent delay & $12 \mathrm{~min}$. \\
Dry air flow & $350 \mathrm{~mL} / \mathrm{min}$. \\
$\mathrm{H}_{2}$ flow mode & $35 \mathrm{~mL} / \mathrm{min}$. \\
$\mathrm{N}_{2}$ flow mode & $20,227 \mathrm{~mL} / \mathrm{min}$. \\
Carrier gas & $\mathrm{He}$ \\
He flow mode & $1 \mathrm{~mL} / \mathrm{min}$, constant flow mode \\
\hline
\end{tabular}

\section{Discussions}

The edible macrofungi, which are rich in terms of minerals, proteins, fiber, vitamins, and are low in terms of calories and cholesterol, are becoming increasingly important as a food source. Both the results of this study and the previously reported studies have shown that macrofungi are rich in terms of mono- and polyunsaturated fatty acids too. In addition, the studies have shown that macrofungi are an important nutrient sources in terms of minerals too. Wild and cultivated mushrooms species can be an important sources of food to meet the nutritional needs of the growing world population. Besides the wild edible macrofungi are an important source of income both nutrient and economically in many places around the world. However, studies made on the diagnosis of macrofungi were shown that very few of the edible macrofungi are known and consumed by the local people.

Table 3. Fatty acid profile of five wild edible mushrooms (\%)

\begin{tabular}{|c|c|c|c|c|c|}
\hline Fatty Acid Type & A. benesii & A. vaginata & L. aurantiacum & M. phaeodisca & S. imbricatus \\
\hline Pentadecanoic acid (C15:0) & ND & ND & 1.83 & ND & ND \\
\hline Palmitic acid (C16:0) & 19.95 & 20.68 & 14.93 & 30.70 & 15.95 \\
\hline Palmitoleic acid (C16:1) & ND & ND & ND & 2.01 & ND \\
\hline Stearic acid (C18:0) & 12.59 & 4.81 & 4.89 & 12.41 & 8.93 \\
\hline Oleic acid (C18:1) & 4.88 & 54.32 & 46.98 & 9.86 & 48.67 \\
\hline Linoleic acid (C18:2) & 62.58 & 20.19 & 31.37 & 45.02 & 26.45 \\
\hline$\Sigma$ SFAs & 32.54 & 25.49 & 21.65 & 43.11 & 24.88 \\
\hline$\Sigma$ UFAs & 67.46 & 74.51 & 78.35 & 56.89 & 75.12 \\
\hline$\Sigma$ MUFAs & 4.88 & 54.32 & 46.98 & 11.87 & 48.67 \\
\hline$\Sigma$ PUFAs & 62.58 & 20.19 & 31.37 & 45.02 & 26.45 \\
\hline
\end{tabular}

Table 4. Mineral levels of mushroom samples ( $\mathrm{mg} / \mathrm{kg}$ )

\begin{tabular}{lcccccc}
\hline Species & $\mathbf{C u}$ & $\mathbf{M n}$ & $\mathbf{Z n}$ & $\mathbf{N i}$ & $\mathbf{F e}$ & $\mathbf{A l}$ \\
\hline Agaricus benesii & 58.96 & 15.74 & 97.43 & 9.62 & 85.95 & 309.10 \\
Amanita vaginata & 60.25 & 69.90 & 104.61 & 15.29 & 1631.86 & 3349.02 \\
Leccinum aurantiacum & 41.11 & 19.30 & 77.33 & 9.10 & 227.38 & 480.28 \\
Macrolepiota phaeodisca & 61.18 & 10.33 & 53.68 & 4.81 & 53.92 & 93.77 \\
Sarcodon imbricatus & 66.16 & 7.18 & 112.29 & 5.38 & 35.45 & 94.49 \\
\hline
\end{tabular}

The results of this study provide us with information on the fatty acid and some mineral contents of five different wild edible macrofungi species that are A. benesii, A. vaginata, L. aurantiacum, M. phaeodisca, S. imbricatus. For some of these mushroom species, no studies can be found on the analysis of fatty acid or mineral content. According to results of the present study, the analyzed macrofungi can be sorted according to total unsaturated fatty acid content like $L$. aurantiacum $>S$. imbricatus $>A$. vaginata $>A$. benesii $>M$. phaeodisca. Evaluation of mineral analysis results show that $A$. vaginata is richer in $\mathrm{Mn}, \mathrm{Ni}, \mathrm{Fe}$ and $\mathrm{Al}$ while $S$. imbricatus is in $\mathrm{Cu}, \mathrm{Zn}$ than the other mushroom specimens under discussion. This reported study will contribute to the studies on this subject.

\section{Conflict of Interest}

Authors have declared no conflict of interest.

\section{Authors' Contributions}

The authors contributed equally.

\section{Acknowledgments}

The authors would like to thank the experts of Bingol University Central Research Laboratory for assistance at chemical analysis.

\section{References}

Akyüz M, Kırbağ S, Karatepe M, Güvenç M, Zengin F (2011). Vitamin and fatty acid composition of P. eryngii var. eryngii. Bitlis Eren University Journal of Science and Technology 1: 16-20.

Al-Fartusie FS, Mohssan SN (2017). Essential trace elements and their vital roles in human body. Indian Journal of Advances in Chemical Science 5(3): 127-136. 
Barros L, Baptista P, Correia DM, Morais JS, Ferreira IC (2007). Effects of conservation treatment and cooking on the chemical composition and antioxidant activity of Portuguese wild edible mushrooms. Journal of Agricultural and Food Chemistry 55(12): 4781-4788.

Barros L, Cruz T, Baptista P, Estevinho LM, Ferreira ICFR (2008). Wild and commercial mushrooms as source of nutrients and nutraceuticals. Food and Chemical Toxicology 46: 2742-2747.

Bengü AŞ (2019). Some elements and fatty acid profiles of three different wild edible mushrooms from Tokat province in Turkey. Progress in Nutrition 21(1): 189-193.

Bengü AŞ, Çınar Yılmaz H, Türkekul İ, Işsk H (2019). Doğadan toplanan ve kültürü yapılan Pleurotus ostreatus ve Agaricus bisporus mantarlarının toplam protein, vitamin ve yağ asidi içeriklerinin belirlenmesi. Turkish Journal of Agricultural and Natural Sciences 6(2): 222-229.

Bon M (1987). The Mushrooms and Toadstools of Britain and North-Western Europe. London: Hodder-Stoughton.

Breitenbach J, Kränzlin F (1995). Fungi of Switzerland. Vol: 4, Agarics 2. Luzern: Verlag Mykologia.

Brzezicha-Cirocka J, Mędyk M, Falandysz J, Szefer P (2016). Bio- and toxic elements in edible wild mushrooms from two regions of potentially different environmental conditions in eastern Poland. Environmental Science and Pollution Research 23: 21517-21522.

Christie WW (1990). The analysis of fatty acids, in gas chromatography and lipids. Glaskow: The Oil Press Ltd.

Christie WW (1998). Gas chromatography-mass spectrometry methods for structural analysis of fatty acids. Lipids 33: $343-353$.

Çolak A, Faiz Ö, Sesli E (2009). Nutritional composition of some wild edible mushrooms. Turkish Journal of Biochemistry 34(1): 25-31.

Dembitsky VM, Terent'ev AO, Levitsky DO (2010). Amino and fatty acids of wild edible mushrooms of the genus Boletus. Records of Natural Products 4(4): 218-223.

Doğan HH, Akbaş G (2013). Biological activity and fatty acid composition of Caesar's mushroom. Pharmaceutical Biology 51(7): 863-871.

Doğan HH (2016). Fatty acid compositions of two mushrooms in Turkey. International Journal of Recent Scientific Research 7(4): 863-871.

Duda-Chodak A, Błaszczyk U (2008). The impact of nickel on human health. Journal of Elementology 13(4): 685-696.

Ergönül PG, Ergönül B, Kalyoncu F, Akata I (2012). Fatty acid compositions of five wild edible mushroom species collected from Turkey. International Journal of Pharmacology 8(5): 463-466.

Fernandesa Â, Barros L, Barreira JCM, Antonio AL, Oliveira MBPP, Martins A, Ferreira ICFR (2013). Effects of different processing technologies on chemical and antioxidant parameters of Macrolepiota procera wild mushroom. Food Science and Technology 54(2): 493-499.

Goyal R, Grewal RB, Goyal RK (2015). Fatty acid composition and dietary fibre constituents of mushrooms of North India. Emirates Journal of Food and Agriculture 27(12): 927-930.

Hara A, Radin NS (1978). Lipid extraction of tissues with a low-toxicity solvent. Analytical Biochemistry 90: 420-426.

Hawksworth DL, Kirk PM, Sutton BC, Pegler DN (1996). Ainsworth and Bisby's Dictionary of the Fungi, 8th edition, Wallingford: CAB International.

Hawksworth DL (2001). The magnitude of fungal diversity: the 1.5 million specie estimate revisited. Mycological Research 105(12): 1422-1432.

Işı1ldak Ö, Türkekul İ, Elmastaş M, Tüzen M (2004). Analysis of heavy metals in some wild-grown edible mushrooms from the middle black sea region, Turkey. Food Chemistry 86: 547-552.

Jonnalagadda SB, Pienaar DH, Haripersad K (2006). Elemental distribution in selected Agaricus and Rhizina mushrooms in South Africa. Journal of Environmental Science and Health Part A 41(3): 507-514.

Jordan M (1995). The Encyclopedia of Fungi of Britain and Europe. London: Frances Lincoln.

Karliński L, Ravnskov S, Kieliszewska-Rokicka B, Larsen J (2007). Fatty acid composition of various ectomycorrhizal fungi and ectomycorrhizas of Norway spruce. Soil Biology and Biochemistry 39: 854-866.

Kawahara M, Konoha K, Nagata T, Sadakane Y (2007). Aluminum and human health: Its intake, bioavailability and neurotoxicity. Biomedical Research on Trace Elements 18(3): 211-220.

Keleş A, Gençcelep H, Demirel K (2017). Elemental composition of naturally growing wild edible mushroom. Journal of Natural Product and Plant Resources 7(4): 37-44.

Moser M (1983). Keys to Agarics and Boleti. Stuttgart: Gustav Fischer Verlag,

Orsine JVC, Novaes MRCG, Asquieri ER (2012). Nutritional value of Agaricus sylvaticus; mushroom grown in Brazil. Nutrición Hospitalaria 27(2): 449-455.

Pedneault K, Angers P, Gosselın A, Tweddell RJ (2006). Fatty acid composition of lipids from mushrooms belonging to the family Boletaceae. Mycological research 110: 1179-1183.

Pekşen A (2013). Mantarların insan hayatı ve sağlığındaki yeri. Bahçe Haber 2: 10-14.

Phillips R (1981). Mushrooms and Other Fungi of Great Britain \& Europe, London: Pan Books Ltd. 
Pietrzak-Fiećko R, Gałgowska M, Bakuła S (2016). Fatty Acid Composition in Wild Boletus edulis from Poland. Italian Journal of Food Science 28(3): 402-411.

Radulescu C, Stihi C, Busuioc G, Popescu IV, Gheboianu AI, Cimpoca VGH (2010). Evaluation of essential elements and heavy metal levels in fruiting bodies of wild mushrooms and their substrate by EDXRF spectrometry and FAA spectrometry. Romanian Biotechnological Letters 15(4): 5444-5456.

Ribeiro B, Guedes de Pinho P, Andrade PB, Baptista P, Valentão P (2009). Fatty acid composition of wild edible mushrooms species: A comparative study. Microchemical Journal 93: 29-35.

Türkekul İ, Çetin F, Elmastaş M (2017). Fatty acid composition and antioxidant capacity of some medicinal mushrooms in Turkey. Journal of Applied Biological Chemistry 60(1): 35-39.

Ravikrishnan V, Naik P, Ganesh S, Rajashekhar M (2015). Amino acid, fatty acid and mineral profile of mushroom Lentinus polychrous lév. from Western Ghats, Southern India. The International Journal of Plant, Animal and Environmental Sciences 5(1): 278-281.

Wada O (2004). What are trace elements? Their deficiency and excess states. Journal of the Japan Medical Association 47(8): 351-358.

Wretensjö I, Svensson L, Christie WW (1990). Gas chromatographic-mass spectrometric identification of the fatty acids in borage oil using the picolinyl ester derivatives. Journal of Chromatography A 521: 89-97.

Woldegiorgis AZ, Abate D, Haki GD, Ziegler GR, Harvatine KJ (2015). Fatty acid profile of wild and cultivated edible mushrooms collected from Ethiopia. Journal of Nutrition \& Food Sciences 5(3): 360.

Yilmaz N, Solmaz M, Türkekul İ, Elmastaş M (2006). Fatty acid composition in some wild edible mushrooms growing in the middle Black Sea region of Turkey. Food Chemistry 99: 168-174. 